\section{Analysis of hepatitis C virus infection among sickle cell anemia patients by an antigen-antibody combination assay}

\section{Obeid E. Obeid, ${ }^{1}$ Alhusain J. Alzahrani \\ Department of Microbiology, College of Medicine, University of Dammam, Saudi Arabia}

\section{Abstract}

Hepatitis $\mathrm{C}$ virus (HCV) has a major impact on public health. In spite of the progress made in the prevention of transfusion-transmitted infections over the last years, these still occur, especially in multi-transfused patients such as sickle cell anemia patients. Sickle cell disease (SCD) is highly prevalent in Eastern Saudi Arabia. Little is known about the prevalence of HCV in Saudi sickle cell disease patients. The present study aimed to assess HCV and HBV antigens, antibodies and viral genome among sickle cell anemia patients in a tertiary hospital in Eastern Saudi Arabia. Methods used included measurement of HCV antigen and antibodies using the novel HCV antigen/antibody combination assay, assessment of HCV core antigen and measurement of viral genome using standard commercial kits. Of the 138 sickle cell disease samples tested, $\mathbf{5}$ (3.6\%) samples gave positive results. Their hemoglobin ranged between 7.8 and $10.1 \mathrm{~g} / \mathrm{dL}$, their erythrocyte count ranged between $3.1 \times 10^{6}$ and $3.9 \times 10^{6}$. Out of these 5 samples, 4 were also positive by the HCV Core Ag assay and by the HCV RNA PCR test (80\%). None of the control group was positive. Seven patients were positive for HBs antibodies. One sample was positive for $\mathrm{HBsAg}$, and this indicates chronic carrier state. Improving the testing for blood-borne infections such as HCV and HBV will result in better control of these infections in sickle cell disease patients which will inevitably lead to lower mortality and morbidity in this group of patients.

\section{Introduction}

Hepatitis $\mathrm{C}$ virus (HCV) is a small enveloped positive-strand RNA flavivirus. With an estimated 170 million infected individuals, HCV has a major impact on public health. ${ }^{1} \mathrm{HCV}$ is primarily transmitted parenterally. Recreational injection drug use (IDU) has been and continues to be the dominant mode of $\mathrm{HCV}$ acquisition. $^{2}$ Risk of HCV transmission through needle stick injury is in the order of 1$3 \%$, compared with $30 \%$ for hepatitis B virus and $0.3 \%$ for HIV. ${ }^{2-4}$

The initial laboratory test is usually an enzyme immunoassay (EIA) for HCV antibodies (anti-HCV). The $3^{\text {rd }}$ generation anti-HCV EIA has a sensitivity of $95-99 \%$ and can detect HCV antibodies 6-8 weeks after exposure. ${ }^{1}$ Polymerase chain reaction (PCR) methods detect the presence of HCV RNA much earlier, at 1-3 weeks after exposure.

More recently, HCV antigen assays have become available which demonstrate that $\mathrm{HCV}$ core antigen detection can significantly reduce the window period prior to detection of antibody. ${ }^{5-7}$ Studies have shown that the average time from the first viremic bleed to the first HCV antigen (Ag) positive bleed is estimated at 2.0 days and the average time to the first HCV antibody (Ab) positive bleed at 50.8 days. $^{3}$

One of the newest assays, the HCV Ag/Ab combination assay, combines the detection of anti-HCV antibodies with the detection of core antigen in a single assay, significantly reducing the window period from infection to detection compared with conventional serological HCV antibody screening assays. ${ }^{8}$

In spite of the progress made in the prevention of transfusion-transmitted infections over the last years, these still occur especially in multi-transfused patients such as sickle cell anemia patients. ${ }^{9-11}$ Many patients require chronic transfusions and as a result, substantial proportions of sickle cell patients are at high risk for infection with blood-borne diseases, such as HCV and hepatitis B virus (HBV) infections. ${ }^{12-15}$

The sickle cell gene is common in certain countries. Sickle cell disease (SCD) is highly prevalent in Eastern Saudi Arabia. People who are homozygous (HbSS) have severe disease and life-long anemia. ${ }^{9}$ The $\mathrm{Hb} \mathrm{S}$ gene frequency range was reported to be $0.005-0.145$ in various areas of Saudi Arabia. ${ }^{16}$ A prevalence of sickle trait of $5.7 \%$ was previously reported. ${ }^{17}$

Little is known about the prevalence of HCV in Saudi sickle cell disease patients. ${ }^{18-19}$ The present study was aimed to assess HCV and HBV antigens, antibodies and viral genome among sickle cell anemia patients in a tertiary hospital in Eastern Saudi Arabia.

\section{Materials and Methods}

\section{Patients}

The study used the samples from a previous study. ${ }^{20}$ The study was conducted in a tertiary hospital in Eastern Saudi Arabia over a period of one year (2009-2010). All sickle cell anemia
Correspondence: Obeid E. Obeid, Department of Microbiology, College of Medicine, University of Dammam, P.O. Box 2114, Dammam 331451, Saudi Arabia. Tel. +966.509.929.487

E-mail: oobeid@yahoo.com.

Key words: hepatitis C virus, hepatitis B virus, sickle cell anemia, antigen-antibody assay.

Received for publication: 27 April 2011. Accepted for publication: 2 November 2011.

This work is licensed under a Creative Commons Attribution NonCommercial 3.0 License (CC BYNC 3.0).

CC Copyright O.E. Obeid and A.J. Alzahrani, 2011 Licensee PAGEPress, Italy

Microbiology Research 2011; 2:e26

doi:10.4081/mr.2011.e26

patients attending the hematology clinics of the hospital were included in the study $(n=138)$. Sickle cell disease was confirmed by high performance liquid chromatography (HPLC). Age of the patients included in the study $(\mathrm{n}=138)$ ranged from six months to 61 years (mean 28 years). Both sexes were included (77 males and 61 females). Blood donors were used as control group $(n=56)$. They included 50 males and 6 females with a mean age of 29 years.

Clinical assessment (history and physical examination) was made for all patients. Sickle cell anemia patients were chosen for laboratory assessment of HCV and HBV antigen, antibody and viral genome. Erythrocyte count, reticulocyte count, sickling test and hemoglobin electrophoresis were also performed. Written informed consent was obtained from all individuals included in this study or their parents.

\section{Techniques}

\section{Detection of anti-HCV antibodies}

Anti-HCV antibodies were assayed by a $3^{\text {rd }}$ generation enzyme-linked immunosorbent assay [Axsym HCV version 3.0 (Abbott Diagnostics, Chicago, IL, USA)] and HCV 3.0 ELISA test system (Ortho-Clinical Diagnostics, Raritan, NJ, USA). In addition, the recombinant immunoblot assay (RIBA HCV 3.0; Ortho-Clinical Diagnostics) was used as previously described and in accordance with the manufacturer's instructions. ${ }^{6-7}$

\section{Detection of $\mathrm{HCV}$ core $\mathrm{Ag} \mathrm{HCV}$}

HCV core Ag assay (Ortho-Clinical Diagnostics) was used (including the neutralization protocol) according to the manufacturer's recommendations and as described previously. ${ }^{6-7}$ 


\section{Simultaneous detection of $\mathrm{HCV}$}

antibodies and antigen ( $\mathrm{HCV} \mathrm{Ag/Ab}$

combination assay)

Simultaneous detection of HCV antigen and HCV antibodies was performed by Muresx HCVAg/Ab combination assay (Abbott Murex). Briefly, test specimens and control sera were placed in the wells and incubated for $60 \mathrm{~min}$ to allow the binding of HCV core antigen and HCV antibodies. After washing, peroxidase labeled conjugate was added and the wells were incubated for $60 \mathrm{~min}$. Unbound conjugate was washed and the substrate was incubated for 30 min. Thereafter, the reaction was stopped and the plate was read at $450 \mathrm{~nm} .^{8}$

\section{HCV RNA assays (qualitative)}

To detect HCV RNA, the COBAS AMPLICOR HCV test version 2.0 (Roche Molecular Systems, Branchburg, NJ, USA) was used as described previously and according to the manufacturer's instructions. This assay has a limit of detection of $2.0 \log 10 \mathrm{IU}$ of HCV genotype 1 RNA per $\mathrm{mL}$.

HBsAg, HBs antibodies and HB core antibody total were carried out on an Abbott AxSym machine, using microparticle enzyme immunoassays (MEIA).

\section{Results}

The age of the patients included in the study $(n=138)$ ranged from six months to 61 years (mean 28 years). The patients were seen in the hematology clinic for routine follow up. $\mathrm{CBC}$ and sickling test positive was performed for all patients. All patients included in the study had sickle cell disease, as confirmed by HPLC.

Analysis of HCV antigen and antibody among our study group ( $\mathrm{n}=138$ ) was made by antigen-antibody (Ag-Ab) combination assay. Of the 138 sickle cell disease samples tested, 5 (3.6\%) samples gave positive results (named thereafter samples 1, 2, 3, 4 and 5). Their hemoglobin ranged between 7.8 and $10.1 \mathrm{~g} / \mathrm{dL}$, their erythrocyte count ranged between $3.1 \times 10^{6}$ and $3.9 \times 10^{6}$ (Table 1). Out of these 5 samples, 4 were also positive by the HCV Core Ag assay (samples 1-4). All 5 samples positive by HCV Ag-Ab combination assay (samples 15) were tested for HCV RNA. These samples were found to be positive by the HCV RNA assay ( $80 \%$; none of the control group was positive) (Table 2).

Of the 138 sickle cell patients, 7 patients were positive for HBs antibodies. One sample was positive for $\mathrm{HBsAg}(0.7 \%)$.

\section{Discussion}

Simultaneous detection of antigen and antibody in the same sample helps to narrow the window period. This is defined as the period from acquiring the infection until the detection of the organism. Narrowing the window period will help accelerate patient management, and promote safer blood transfusions and better control of the disease.

Four of the 5 samples positive by the HCV Ag-Ab assay were found to be positive by the HCV Ag assay and the HCV RNA assay. One sample was positive for HCV Ag Ab and has no antigenemia or viremia. This patient may have cleared the virus from the circulation and the only remaining evidence for the HCV infection is the HCV antibodies. The good correlation between the HCV combination assay and the antigen testing and the nucleic acids testing (NAT) may lead to the replacement of the NAT by HCV Ag assay or the new HCV Ag-Ab combination assay. NAT is expensive, needs specialized set up within the hospital laboratories and requires experienced molecular technologists. ${ }^{21}$ On the other hand, the HCV combination assay is based on serological techniques that are easy to perform, less expensive, and do not require a special location or specialized technologist.

Patients who should be tested for HCV RNA include those whose anti-HCV EIA result was inconclusive: immunocompromised patients (e.g. those with HIV or who are undergoing hemodialysis) who may not generate antibodies to infection; patients who are thought to be in a period of acute infection, when the PCR test result will be positive but antibodies have not yet developed; and patients with a positive anti-HCV test result but persistently normal alanine transferase levels. A significant minority of patients who have HCV antibodies and persistently normal liver chemistry test results (especially if alanine transferase values are in the lower half of the normal range) have spontaneously cleared their acute HCV infection but will continue to have detectable HCV antibodies for an indefinite period. The Murex $\mathrm{Ag} / \mathrm{Ab} \mathrm{HCV}$ Combination Assay is an enzyme immunoassay. Wells are coated with anti-core monoclonal antibody, and with recombinant antigen and peptides representing the immunodominant regions of NS3 and core viral antigens. Hence both HCV core Ag and HCV antibodies are detected simultaneously. ${ }^{8}$

The HCV antibody positivity is directly related to the number of transfusions given, and on average the prevalence rate in transfused patients is more than $10 \%$. The prevalence of HCV in our samples was lower than the worldwide average of $10 \%$. This could well be due to the better screening of blood donors in Saudi Arabia. It is known that the combination of iron overload and HCV can lead to a more rapidly progressive liver disease. The treatment of HCV in sickle cell patients poses a challenge to clinicians. A novel approach described by some is the pre-treatment of these patients with hydroxyurea to increase the fetal hemoglobin, therefore decreasing the severity of ribavirinrelated hemolysis. Treatment with Peg-interferon alone has not been used to treat $\mathrm{HCV}$ in sickle cell patients, but in the setting of controlled clinical trials it would be feasible.

Little is known about the prevalence of HCV

Table 1. Hematologic data for the $5 \mathrm{HCV}$-infected sickle-cell anemia patient $(n=5)$.

\begin{tabular}{lcccc} 
Patient & $\begin{array}{c}\text { Gender/ } \\
\text { age }\end{array}$ & $\begin{array}{c}\text { Hemoglobin concentrations } \\
\text { g/dlh (normal value) }\end{array}$ & $\begin{array}{c}\text { Erythrocyte count } \\
\text { millions/ul } \\
\text { (normal value) }\end{array}$ & $\begin{array}{c}\text { Reticulocyte } \\
\text { (normal value) }\end{array}$ \\
1 & $\mathrm{~F} / 35 \mathrm{Y}$ & $9.7(13-18)$ & $3.7(4.5-6.5)$ & $2.5(0.5-2)$ \\
2 & $\mathrm{~F} / 11 \mathrm{Y}$ & $8.4(11-15)$ & $3.5(4-5.6)$ & $3(0.5-2)$ \\
\hline 3 & $\mathrm{~F} / 37$ & $8.5(13-18)$ & $3.59(4.5-6.5)$ & $0.9(0.7-2.8)$ \\
4 & $\mathrm{M} / 26 \mathrm{Y}$ & $7.8(11.5-16.5)$ & $3.1(4.5-6.5)$ & $0.5(0.7-2.8)$ \\
\hline 5 & $\mathrm{M} / 22 \mathrm{Y}$ & $10.1(11.5-16.5)$ & $3.9(4.5-6.5)$ & $0.4(0.7-2.8)$ \\
\hline
\end{tabular}

Table 2. Pattern of reactivity sickle cell disease patients with HCV antigen, antibody and viral RNA.

$\begin{array}{lccc}\text { Group tested } & \begin{array}{c}\text { HCV Ag-Ab } \\ \text { combination } \\ \text { N.(\%) positive }\end{array} & \begin{array}{c}\text { HCV Ag } \\ \text { N. (\%) positive }\end{array} & \begin{array}{c}\text { HCV Viral RNA } \\ \text { N. (\%) positive }\end{array} \\ \begin{array}{l}\text { Sickle cell anemia } \\ \text { N=138 }\end{array} & 4(2.89 \%) & 4(80) & 4(80) \\ \text { Control } & & & 0 \\ \mathrm{~N}=56 & 0 & 0 & \end{array}$


in Saudi sickle cell disease. Al-Fawaz et al. ${ }^{22}$ found that HCVAb positivity was significantly higher in patients with sickle cell amemia (16.0\%) and in thalassemics (57.1\%) than in the respective control groups. Bahakim et al. ${ }^{18}$ reported that $\mathrm{HCV}$ antibodies were detected in $33.3 \%$ of patients with thalassemia and sickle cell disease and in $5.3 \%$ of controls. None of these studies assessed the presence of $\mathrm{HCV}$ antigenemia in Saudi sickle cell disease patients.

Seven patients were positive for HBs antibodies, which may indicate past infection or immunization. One sample was positive for $\mathrm{HBsAg}$, and this indicates chronic carrier state. The low prevalence of HBV among Saudi sickle cell disease patients is likely to be due to the routine vaccination program for $\mathrm{HBV}$. The $\mathrm{HBV}$ recombinant vaccine is given to all children in Saudi Arabia

Improving the testing for blood-borne infections such as HCV and HBV will result in better control of these infections in sickle cell disease patients which will inevitably lead to lower mortality and morbidity in this group of patients.

\section{References}

1. Dwyre DM, Fernando LP, Holland PV. Hepatitis B, hepatitis C and HIV transfusion-transmitted infections in the 21st century. Vox Sang 2011;100:92-8.

2. Fallahian F, Najafi A. Epidemiology of hepatitis $\mathrm{C}$ in the Middle East. Saudi J Kidney Dis Transpl 2011;22:1-9.

3. Irshad M, Ansari MA, Singh A, et al. HCVgenotypes: a review on their origin, global status, assay system, pathogenecity and response to treatment. Hepatogastroenterology 2010; 57:1529-38.

4. Chayama K, Hayes CN. Hepatitis C virus: How genetic variability affects pathobiology of disease. J Gastroenterol Hepatol 2011;26:83-95.

5. Alzahrani AJ. Simultaneous detection of hepatitis $\mathrm{C}$ virus core antigen and antibodies in Saudi drug users using a novel assay. J Med Virol 2008;80:603-6.

6. Alzahrani AJ, Obeid OE. Detection of Hepatitis C virus Core Antigen in Blood Donors using a new Enzyme Immunoassay. FAMCO Journal 2004;11:103-7.

7. Alhusain J, Alzahrani AJ. Analysis of HCV Core Antigenemia in Saudi Drug Users. Saudi Med J 2005;26:1645-6.

8. Alhusain J, Alzahrani, Obeid E Obeid, et al. Detection of Hepatitis $\mathrm{C}$ virus and Human immunodeficiency virus in expatriates in Saudi Arabia by antigen-antibody combination assays. J Infect Dev Ctries 2009;3: 235-8.

9. Meremikwu M. Sickle cell disease. Clin Evid 2006;15:45-59.

10. Alswaidi FM, O'Brien SJ. Premarital screening programmes for haemoglobinopathies, HIV and hepatitis viruses: review and factors affecting their success. J Med Screen 2009;16:22-8.

11. Raphael RI. Pathophysiology and treatment of sickle cell disease. Clin Adv Hematol Oncol 2005;3:492-505.

12. Issa H. Safety of pegylated interferon and ribavirin therapy for chronic hepatitis $\mathrm{C}$ in patients with sickle cell anemia. World J Hepatol 2010;2:180-4.

13. Ocak S, Kaya H, Cetin M, et al. Seroprevalence of hepatitis $B$ and hepatitis $C$ in patients with thalassemia and sickle cell anemia in a long-term follow-up. Arch Med Res 2006;37:895-8.

14. Fasola FA, Odaibo GN, Aken'Ova YA, et al. Hepatitis $\mathrm{B}$ and $\mathrm{C}$ viral markers in patients with sickle cell disease in Ibadan, Nigeria. Afr J Med Med Sci 2003;32:293-5.

15. Lesi OA, Kehinde MO. Hepatitis C virus infection in patients with sickle cell anaemia at the Lagos University Hospital. Niger Postgrad Med J 2003;10:79-83.

16. DeVault KR, Friedman LS, Westerberg $\mathrm{S}$, et al. Hepatitis C in sickle cell anemia. J Clin Gastroenterol 1994;18:206-9.

17. el-Hazmi MA, Warsy AS. Appraisal of sickle-cell and thalassaemia genes in Saudi Arabia. East Mediter Health J 1999;5:114753.

18. Bahakim H, Bakir TM, Arif M, et al. Hepatitis $\mathrm{C}$ virus antibodies in high-risk Saudi groups. Vox Sang 1991;60:162-4.

19. Hasan MF, Marsh F, Posner G, et al. Chronic hepatitis $\mathrm{C}$ in patients with sickle cell disease. Am J Gastroenterol 1996;91: 1204-6.

20. Obeid E Obeid. Molecular and Serological Assessment of Parvovirus B19 Infections Among Sickle Cell Anemia Patients. J Infect Dev Ctries 2011. In press.

21. Al Olaby RR, Azzazy HM. Hepatitis C virus RNA assays: current and emerging technologies and their clinical applications. Expert Rev Mol Diagn 2011;11:53-64.

22. al-Fawaz I, al-Rasheed S, al-Mugeiren M, et al. Hepatitis $\mathrm{E}$ virus infection in patients from Saudi Arabia with sickle cell anaemia and beta-thalassemia major: possible transmission by blood transfusion. J Viral Hepat 1996;3:203-5. 